\title{
Back to Africa: (Re)appropriating the "Back-to- Sender" Concept in the Zimbabwe Catholic Charismatic Renewal
}

\author{
Misheck Mudyiwa \\ https://orcid.org/0000-0003-0783-4844 \\ University of Limpopo \\ fathermisheck@gmail.com
}

\author{
Sekgothe Mokgoatšana \\ https://orcid.org/0000-0002-3224-2341 \\ University of Limpopo \\ Sekgothe.Mokgoatsana@ul.ac.za
}

\begin{abstract}
This article explores the phenomenon of healing and exorcism in the Zimbabwe Catholic Charismatic Renewal (ZCCR). It examines specifically the theological basis and ramifications of the back-to-sender concept that is currently the hallmark and defining feature of most self-styled exorcists in the ZCCR. In its religious settings, the back-to-sender concept underscores that every power that uses witchcraft, magic or otherwise, to suppress, attack, possess or militate against human prosperity and breakthroughs, must be sent back to haunt or destroy their owners and dispatchers. The article provides both the milieu and context(s) within which the concept of back-to-sender possibly emerged and critically analyses the ZCCR healing praxis and the immediate reaction of ecclesiastical authorities. Pivoting on sacred scripture and the Catholic tradition, salient pastoral and theological controversies that emerge from the concept are highlighted and critically examined. The main argument developed in this article is that, while healing in the ZCCR - as manifest in the causal explanations, diagnosis and methodology-lacks sufficient theological evidence either to condemn or approve it, the seemingly borrowed and imported back-to-sender concept is itself problematic and incompatible with a Christology of non-violence, non-retaliation and turning of the other cheek (Matthew 5:38-48). However, it is consistent with the African culture and concept of social justice and equilibrium.
\end{abstract}

Keywords: Zimbabwe Catholic Charismatic Renewal (ZCCR); healing; back-tosender; non-retaliation; Afrocentricity

\section{UNISA $\cong$}




\section{Introduction}

Ever since the introduction of Christianity in Zimbabwe from the 16th century by the earliest White missionaries, exorcism has been a characteristic feature of mostly African Independent Churches (AIC). For decades, AICs have continued to be significant players in Zimbabwe's spiritual market, as it is in South Africa (Chitando et al. 2014, 7). These indigenous Christian communities of Pentecostal ${ }^{1}$ and charismatic character have dominated the area of faith healing for decades. Yet, within most phlegmatic denominations, particularly the Roman Catholic Church, there has been that dormant, as yet inarticulate yearning for the same healing methodology (Mudyiwa 2016, 21). While the Roman Catholic Church has for decades clung resolutely to the belief in the healing abilities of both the Sacrament of the Anointing of the Sick ${ }^{2}$ and church-related conventional healthcare systems, critics have, however, persistently argued that Western medicine does not provide complete answers and solutions to a myriad of African health problems. For centuries, Africans have always believed in their inherited cosmological wisdom, which underlines that "illness and suffering are no experiences that concern only man's physical substance, but a man in his entirety and somaticspiritual unity" (Zimbabwe Catholic Bishops' Conference [ZCBC] 1989, 7).

Scholars such as Daneel (1987) and Lagerwerf (1992) are among the fiercest critics of the missionary approach to African health problems. The duo concurs that while the healing apostolate of the early missionaries helped them (missionaries) to get closer to the local people and to understand their philosophy on a one-on-one basis, the area of witchcraft, sorcery, spirit possession and deliverance remained unaddressed. Consequently, this created substantial metaphysical gaps and cracks that called for urgent pastoral attention, particularly within the Mother Church. As underscored by Largerwerf $(1992,1)$, in sub-Saharan Africa, unfortunately, most mainline churches (including the Roman Catholic Church) did not seem to take the fears of the local converts seriously in this regard, as "Western medicine and approaches in most cases did not probe sufficiently into the spiritual causes of the African people" (Daneel 1987, 77-78).

Quoting from Pretorius, Daneel $(1987,77)$ openly and unequivocally accuses missionaries of preaching a superficial and impoverished gospel. Inevitably, this made them fail to see the validity of an entirely different cosmological system of thought from their own, he argues. Daneel $(1987,77)$ calls this miscalculation "a cosmological underestimation." This cosmological underestimation subsequently created a culture of double-dealing amongst most local Christian (particularly Catholic) converts. In times

1 An undisputed and uncontested demonstration of spiritual gifts, personal encounters with God/hierophany and an unquestionable display of power over Satan, demons and principalities of darkness are often regarded as the main characteristics of Pentecostalism.

2 The Sacrament of Anointing of the Sick is administered by priests and bishops to sick members of the Roman Catholic community by anointing them on the forehead and palms with duly blessed olive oil (The Catechism of the Roman Catholic Church 1994, no. 1513). 


\section{Mudyiwa, Mokgoatšana}

of serious illnesses that they felt did not require either the traditional Sacrament of the Anointing of the Sick or conventional medical approaches, they often sneaked out to seek assistance from traditional healers and AICs within their proximity. Faced by such a demanding and dicey situation that called for urgent pastoral attention, the Roman Catholic Church thus needed to read the signs of times to remain relevant both theologically and pastorally. The Roman Catholic Church needed to urgently adopt and adapt to the changing pastoral environments to transcend the conventional healing methods in diagnosis and therapy in order to remain compatible and pertinent in the ever-changing Christian landscape. Ever since the introduction of the ministry of healing by Fr Augustine Urayai of the Catholic Diocese of Gweru back in 1969 (Sibanda 1999, 14), a handful of other Catholic priests from dioceses such as Harare, Mutare, and Gokwe, among others, have since woken up from their slumber of dogmatic and conventional parochialism by reviving and resuscitating the seemingly dormant Zimbabwe Catholic Charismatic Renewal (ZCCR). As they battle it out with powers and principalities of darkness, these Catholic demon fighters have been popularised by the deployment ${ }^{3}$ of the back-to-sender methodology. This approach is currently fashionable and voguish among most Pentecostal and charismatic healing communities. Even though the initial phase of the revival was characterised by a visible disengaged and detached approach from a handful of bishops, driven by some clergy and lay enthusiasts and aficionados, the movement has to date grown to be like the biblical mustard seed (Mark 4:30-32) ${ }^{4}$ and is now established in five of the country's eight dioceses (Matambo 2015, para 4).

\section{Methodology and Theoretical Lens}

To capture the information that this article sought to unravel, the authors used two main research tools: interviews and participant observation. Among many other things, participant observation allowed the authors to attend several Catholic charismatic healing sessions, particularly those conducted during and outside Holy Mass like the popular and crowd-pulling All Night Prayer sessions. During interviews, particular attention was given to the anonymity and confidentiality of participants. For that reason, participants who requested anonymity have not been divulged but given pseudonyms. Interviews are chief instruments of the oral history method, where history is documented from below. Oral history gives voice to people commonly muted and marginalised. Unlike documentary history, its focus is not primary evidence in the traditional archive, but oral sources, narratives, testimonies, and versions as offered by people who have a first account of the events or experience, or at best have received the stories as handed

3 Chitando and Tarusarira (2017) examined how indigenous spirituality and terminologies are sometimes manipulated in justifying violence and wickedness. The two examined, in particular, how the sacred Shona song "Zimbabwe ndeye ropa raMadzibaba" (Zimbabwe was/is born of the blood of the Fathers/Ancestors) is often deployed and appropriated to sacralise violence in Zimbabwean politics.

4 All references to Bible verses are from The Jerusalem Bible 1966. 
down by tradition. Grele $(2007,14)$ contends that interviews as constructed texts about the usable past are deeply connected to remembering.

Remembering as memory provides for variability, which is a key component of oral history. These truths are not absolute, but socially constructed. For Grele $(2007,11)$, the interview is both a public and performative text, "a blending [of] the negotiation of the individual and collective remembering." The versions collected as tissues of memory and representations of the past are variable. These variations take various forms, structures, and content (Finnegan 2012, 12; Junod 1913, 200; Mokgoatšana 2020a, 3). The oral historical narratives are collected through interviews transcribed to produce various versions of the same narrative (proto-narrative) to establish historical truth. Consequently, an interview is a transactional act, a dialogue, and a conversation between the interviewer and the interviewee as a repository and receptacle of knowledge.

To this end, oral history conversations revolutionise the research landscape by bringing into the research space tissues of memory, usually stripped out of research through phenomenological constructs such as thinking away and acting away in pursuit of objectivity. Oral history, therefore, brings into the mainstream of research a voice normally obfuscated, and pushed through obscurantism by research traditions considered canonical. This voice, sometimes, is coincidentally the African voice. For this reason, the methodological and the theoretical are interwoven seamlessly, connecting the Afrocentric to conversations drawn from it.

Because the notion of the "back-to-sender" phenomenon is largely an African experience, before exploring the history of the ZCCR and the "back-to-sender" methodology currently employed by most Catholic clergy exorcists, it is vitally predominant and paramount that the article briefly examines the Afrocentric lens on which the argument rests to appreciate the importance of health and well-being among African Christian converts.

\section{Afrocentricity and the Premise of Knowing and Interpreting}

Mokgoatšana (2020b) has recently published an article discussing the symbolism of the kgolomodumo (monster) to demonstrate Sepedi eschatology. What the article does theoretically, is to show the relevance of interpreting African phenomena from an African perspective. This kind of theorisation was popularised by Maulana Karenga's Kawaida Theory that centralised African culture as the fulcrum of interpreting reality and seeking an identity in all things African, as well as Molefi Asante's theory of Afrocentricity (Asante 1998; Karenga 2014). We can, without fear of contradiction, proclaim that Maulana Karenga's Kawaida Theory is Afrocentric. Without understanding the cosmological world that informs the interpretation of reality in Africa, theorising about Africa often displaces the ethnographic constructions of the community in question. Afrocentricity, therefore, provides the prism to understand the culture in its totality, recognising the place of (w)holiness, indivisibility and the 
interwovenness of aspects of reality. This means the teleological, axiological, epistemological, locational, psychic, cosmological and the metaphysical are bound together as one.

Understanding the intricacy and complexity of the African traditional worldview is thus critical and foundational in any discussion about healing and exorcism among African Christians. From a typical African contextual landscape, the fact that the African traditional religion is complex and elaborate cannot be denied. However, the belief in spirits, witchcraft, and spirit possession is a common phenomenon, particularly within the Shona/Ndebele traditional spirit worldview that largely shaped most Catholic healing ministers in Zimbabwe. Zvarevashe $(2005,2)$ posits that while Zimbabwe is a multi-religious country, it is also a multi-ethnic society, comprising more than 10 ethnic groups of diverse backgrounds, which historians and anthropologists have lumped into two main ethnic groups, namely the vaShona people and the AmaNdebele clan.

Like most Africans, the vaShona and AmaNdebele people believe that illness is often caused by none other than some evil people with some evil influence of a spiritual nature, the cure of which consists in eliminating that harmful spiritual influence or the person himself or herself. Armed with such beliefs and assumptions, the genuine traditional Shona/Ndebele society (like the whole of Africa) does not ask the question: What has caused the illness? Rather, they ask: Who has caused the illness? (ZCBC 1989, 16). Following the same logic and African cosmological system of thought, when such indigenous people approach the gospel, they do so with heightened healing expectations and hopes. They always expect their priests and pastors to display unparalleled abilities and skills in wrestling with witchcraft, sorcery and spirit possession, employing some spiritual means to confront, quarantine and conquer. They expect their religious ministers and priests to be armed with supernatural powers to cure and heal their infirmities, to defeat, destroy and dismantle powers and principalities of darkness.

While the Roman Catholic Church has been continuously accused of preaching an impoverished gospel by failing to address African health problems (Daneel 1987, 7778), the 21st-century crop of Zimbabwe Catholic priests seems to have read the signs of times. A handful of junior and senior Roman Catholic priests in Zimbabwe have injected new life and blood into the Roman Catholic healing ministry by reviving and resuscitating the seemingly dormant charismatic renewal in the Zimbabwe Catholic Church. Through their knowledge of supernatural realities, coupled with a display of some healing skills and techniques that demonstrate the presence of the Holy Spirit at work, this team of exorcists has not just read the signs of the times but also opened a new chapter in the history of the Zimbabwe Catholic Church, much to the appreciation of some sections of the Catholic community in Zimbabwe. Before highlighting their healing praxis and methodology, for which they are particularly famous, it is academically pivotal and meritorious to revisit the history of Roman Catholic charismatic movements. 


\section{Roman Catholic Charismatic Movement: An Overview}

Matsikidze (2015), Matambo (2015) and Ciciliot (2019), among many others, explored the birth and development of the Roman Catholic Charismatic Movement (CCM) in the history of Christianity. The trio confirms that the CCM was officially born in 1967 in the United States of America (USA) when a group of Catholic and Methodist university students and staff prayed separately and instantly received gifts of the Holy Spirit, such as prophecy, faith healing and speaking in tongues. Such amazing and unprecedented experiences were epoch-making and life-changing, not just for these pioneer charismatics but for Christianity as a whole.

As the electrifying account of the outpouring of the Holy Spirit in a manner that resembled the biblical Pentecostal episode in all its essentials gossiped around, many colleges, universities, parishes and other Roman Catholic institutions were also eager to make similar experiments. Charismatic experiments were conducted in several places and apparently, they yielded similar spectacular spiritual results. Thereafter, though devoid of Pontifical clearance, a Pentecostal and Charismatic character's innumerable healing movements flourished in the USA like a veld fire. Subsequently, Roman Catholic healing movements were exported out of America, curtesy of mostly priests, religious and lay faithful who-after visiting the USA-implemented similar organisations in their respective countries and workplaces (Ciciliot 2019, 150-151).

Ciciliot (2019) further underlines that wherever these national and international organisations and charismatic networks were marketed and planted, they were packaged and tailor-made to draw Christians into deeper spiritual life than before and moved them (Christians) towards experiencing God's love more deeply, "and appreciated even more deeply the spiritual riches to be found in the Catholic Church" (Matambo 2015, para 3). With their ability to attract thousands of people, such vibrant charismatic conferences and movements only needed approval from the Magisterium, particularly the then reigning pontiff, Paul VI (1897-1978) for them to become truly Catholic, orthodox and canonical. To that effect, after some careful consultations and reflection, the Roman Pontiff, together with several cardinals and bishops who had been initially cautious and sceptical about the character of the movement, appended their ecclesiastical signatures in approval. After that, the CCM became legitimately Catholic and conventional. Several other pontiffs who came after Paul VI, such as John Paul II (1920-2005), Benedict XVI (2005-2013) and the incumbent Pope Francis, have also endorsed the $\mathrm{CCM}$ as an ecclesial movement endowed with pristine and uncharted spiritual benefits. Despite the endorsement, a handful of Local Ordinaries, however, simply observed the movement without approving or disapproving it in their respective constituencies.

It is believed that in Zimbabwe, the $\mathrm{CCM}^{5}$ was introduced in the late 1970s by $\mathrm{Fr}$ Michael Hout (SJ) of the Archdiocese of Harare. Fired up with the passion and zest to make Rhodesian (now Zimbabwean) Catholicism charismatic, the Jesuit clergyman

5 In this article, ZCCR and CCM are at times used interchangeably. 


\section{Mudyiwa, Mokgoatšana}

laboured to introduce the movement in the then Diocese of Salisbury (now Harare) before introducing it to the Diocese of Bulawayo in 1980. However, ironically, his efforts were shocked when the then incumbent Local Ordinary accused him of misleading the laity and diluting Roman Catholic liturgy with his overzealous charismatic campaigns. Sadly, he was, however, asked to stop his campaigns and leave the country before the movement had gathered enough momentum to produce lasting fruits. His departure marked the end of the first phase of charismatic campaigns in Zimbabwe (Anonymous Priest, Interview 20 November 2020).

The fundamental belief that cuts across CCMs, is that the same Biblical Holy Spirit still bestows the assumption that gifts of the Holy Spirit underlined in Paul's First Letter to the Corinthians (I Cor 12:1-11) (2000 years after Christ) as they were on the day of Pentecost (Acts 2:1-31) and among the early Christian community. While the main aim of the CCM has always been to refresh, re-energise and re-vitalise the entire Roman Catholic Church through the infinite power and wisdom of the Holy Spirit (Matsikidze 2015), the same movement has never been as pronounced, visible and relevant in Zimbabwe as in the 21st century, some two decades after the unceremonious departure of Fr. Hout. In as much as the need to revive the charismatic dimension of the Roman Catholic Church could be attributed to some factors, "stealing of sheep" by Pentecostal and charismatic communities (who have always employed and maintained an African approach in their healing methodology, diagnosis and causal explanations), cannot be overemphasised.

Since the ministry of healing and deliverance was largely dominated by some Shona Independent Churches of a charismatic and Pentecostal character, particularly Zionism which incorporated many traditional African beliefs, a handful of Catholic priests always yearned to introduce such a ministry in their own Roman Catholic Church to curb the problem of "sheep stealing" and double-dealing that have been prevalent among many Catholics since then. Myers (2011) observed the world over, from house churches to mega-churches, almost all churches "steal sheep" from other churches and these "sheep" also have a tendency of going where the grass is greener or greenest. In this regard, grass has always been the greenest where there was an undisputed and uncontested demonstration of spiritual gifts, personal encounters with God/hierophany and an unquestionable display of power over Satan and demons. Grass has always seemed the greenest where faith healing was displayed and demonstrated.

Ever since new impetus was injected into the ZCCR at the beginning of the new millennium, priests from dioceses such as Harare, Bulawayo, Hwange, Mutare, Chinhoi and Gokwe are at the mecca and nucleus of crowd-pooling charismatic healing gatherings that are sometimes conducted on a rotational basis in different local dioceses. Two dioceses, namely, Masvingo and Gweru have, however, maintained a position of benevolent neutrality even though their clientele often sneak out to attend charismatic gatherings elsewhere (Portia Chiraza, Interview 20 August 2020). While ZCCR, led by this new brand of liberal Roman Catholic priests, currently offers solutions to various 


\section{Mudyiwa, Mokgoatšana}

challenges faced mainly by Catholic clientele, of particular concern in subsequent segments is the deployment of the back-to-sender methodology in their vibrant and electrifying healing sessions. In contradistinction to the healing methods of pioneer exorcists such as Fr. Augustine Urayai of Zimbabwe (1931-2003), Bishop Milingo of Zambia (1930) and Fr. Nkwera of Tanzania (1936), who are perhaps regarded among the best known Catholic exorcists in sub-Saharan Africa today, as underlined earlier, the current crop of self-styled exorcists in the ZCCR has since carved their healing methods targeted at wading off powers and principalities of darkness that militate against the health and prosperity of their "sheep." While methodologies of necessity may differ from exorcist to exorcist, diocese to diocese and from one healing session to another, there are several striking points of similarities, "regardless of whether the healing session takes place outside Holy Mass, within Holy Mass, during Benediction or an All Night Prayer" (Anonymous, Interview 20 September 2018).

\section{Deliverance outside Holy Mass}

Deliverance outside the Eucharistic celebration (Holy Mass) is a common phenomenon and practice among ZCCR ministers. As observed and witnessed by one of the authors in several dioceses, such sessions could be conducted with or without the availability of priests, who by their ecclesiastical office are without any doubt or scepticism, the key strategic players in the back-to-sender healing methodology. While methodologies may differ as already underlined, in most cases, each deliverance session outside the celebration of Mass often begins with a short background preparation (Anonymous, Interview 20 September 2018).

Background preparation usually takes the form of a hymn, opening prayer and gospel sharing on any suggested suitable theme. Depending on circumstances, Lectio Divina or spiritual input from a guest often characterises this critical initial stage. The Lectio Divina format, which is the most popular, simply means "divine reading." Frontline writers on Lectio Divina such as Leonhardt (2009), Burke (2012) and Manneh (2020) concur that Lectio Divina is reflecting prayerfully on God's Word. It defines and describes a special way of reading the scriptures, whereby congregants let go of their agenda and open themselves to what God wants to say to them. As underlined by Manneh (2020), Lectio Divina comprises four main stages. Stage one is the lectio (reading) of sacred scripture. At this initial stage, the Bible is read carefully, slowly and reflectively so that the message sinks into all participants' hearts. Any biblical passage may be used, though shorter passages that are more direct are often preferred to longer ones that may be winding, time-consuming and confusing. After lectio comes meditatio (meditation). At this second stage, congregants think about the text they would have read, ruminate upon it so that they take from it only what God wants to give them. Oratio (response) comes immediately after meditation. Congregants are encouraged at this stage to leave their thinking aside and simply let their hearts speak to God, the Creator, Sustainer and Healer of their lives. The last stage is the contemplatio (rest, contemplation) whereby participants let go not just of their ideas, plans and meditations but also their words and thoughts. They rest in the word of God and listen with their 


\section{Mudyiwa, Mokgoatšana}

inner ears at their deepest levels to what God speaks to them so that they are subsequently transformed from within (Burke 2012). As underlined earlier, if the Lectio Divina method is not employed, a guest (priest, brother, sister or layperson) may introduce the healing session by giving a spiritual input on any theme of choice before introducing the next stage.

Reflecting prayerfully on God's Word or listening to a spiritual input from a guest is immediately followed by the singing of praise and worship songs (Anonymous, Interview 10 August 2018). Both clergy and laity, who often gather for healing sessions in the aforementioned Catholic dioceses, believe in the power and efficacy of spontaneous praise and worship, which they believe is firmly rooted in sacred scripture. Music has always been electrifying in both church and political circles. There is overwhelming evidence that the 1 st century Christians used well-known hymns in their worship (Adarkwa 2015, para 8). Praise and worship also find justification in the scriptures. Whereas Paul talks about singing as a declaration of thanks (Heb 13:15), King David adds, "with clapping of hands and shouting (Psalm 47:1), musical instruments and dancing (Psalm 150:4), making joyful noise (Psalm 98:4), by lifting our hands (Psalm 134:2) and by being loud" (Psalm 33:3; 95:1-6).

Thus, loud music has always drawn congregants closer to God, and for most African Christians, it gets them started. They believe music is an expression of God's worth, an expression of the purpose for which humanity was created. It puts them all in the right mind-set, thereby ushering in God's presence and infinite healing power. As noted by the Discipleship Ministries (2007, para 5), through music the call of God reaches the depths of people's hearts with a special power, and their singing expresses with special power the deepest responses of their hearts to God. When congregants praise and worship, they are elevated into God's majestic presence and magnetic power. They are spiritually strengthened and collectively declare war against humanity's arch-enemy (the Devil) who is ever prowling like a roaring lion, looking for someone to devour (1 Peter 5:8). While hymns that best suit the faith-healing occasion are often used during charismatic renewal sessions, those that glorify God and invite the Holy Spirit (like Baba Munoera-Father You are Holy Indeed) often dominate any healing session at this crucial stage (Anonymous, Interview 15 August 2018). The singing of praise and worship songs is often expected, among many other things, to drive many participants into a trance, individual spontaneous prayers, jumping up and down, rolling on the floor, beating walls or dashing out of the church or hall; not necessarily as a sign of spirit possession but an indication of visible ecstasy. In Harare Diocese, one interviewee had this to say:

In some cases, after the freestyle prayer session, the minister simply announces and makes it clear that it is now time for healing. After the announcement, the ministers present would then go around laying hands on everyone present. During this time, evil spirits would then start to manifest.... In other cases, however, depending on the presiding minister, congregants are asked to pronounce certain words or simply call the name of Jesus. Words such as VICTORY, NEIGHBOUR or JESUS are the most 
common. The moment the minister repeats the same word two or three times, manifestations then begin.... To counter these manifestations, back-to-sender pronouncements are then showered by the presiding minister. (Tafadzwa Midzi, Interview 15 August 2018)

Declarations of the back-to-sender are often pronounced when there is irrefutable evidence of spirit possession during this electrifying period of praise and worship. As underlined in earlier segments, taking cognisance of the fact that misfortunes, which affect African Christians, such as sickness, affliction, spirit possession, poverty (among others) are often associated with people harbouring evil intentions, the leading priest or minister timely makes the back-to-sender pronouncements so that anything that would have affected or possessed any member of the congregation could be sent back to haunt their owners or may scatter into desolation or fall and die in the name of Jesus (Tafadzwa Midzi, Interview 15 August 2018). While such declarations could take several forms, most of them often resemble some striking similarities. Below is one common format:

Minister: Every power monitoring your life for evil!

Congregation: Back to the sender in the name of Jesus!

Minister: Every power plotting your downfall!

Congregation: Backfire in the name of Jesus!

Minister: Every negative plan, projection or manipulation!

Congregation: Back to the sender in the name of Jesus!

Minister: Every evil wish, imagination or sacrifice carried against you!

Congregation: Backfire in the name of Jesus!

Minister: Every power that wants to block your breakthrough!

Congregation: Back to the sender in the name of Jesus!

It is also a common practice and phenomenon that after the back-to-sender pronouncements, priests and other ministers available would lay hands upon all the afflicted amidst more singing, visible spirit manifestations and speaking in tongues. In most cases, back-to-sender declarations and laying of hands, however, often happen simultaneously. At this stage, innumerable devotees have confessed and acknowledged that their participation in the Catholic charismatic healing sessions had brought imminent answers and solutions to their day-to-day problems. Laying hands on every/most participants would then lead to the closing prayer and final blessing. By the time this research was being conducted, lay ministers were being discouraged from laying hands on the heads of the visibly possessed, sick, or afflicted. Instead, they were encouraged only to lay their hands on the victims' shoulders as they meditatively pray for them and wrestle with powers and principalities of darkness (Charity Chidziva, Interview 12 August 2018). 


\section{Deliverance during the Celebration of Holy Mass ${ }^{6}$}

Inseparably linked to healings and exorcisms that take place outside Mass, are deliverances that are often conducted during the celebration of Holy Mass. According to The Catechism of the Roman Catholic Church $(1994,341)$, the liturgy of the Eucharist or Holy Mass unfolds in line with the fundamental structure that has been preserved throughout the centuries, to this day. The traditional sacrosanct structure displays two key parts that form a fundamental and unbreakable unity, namely the liturgy of the word and the liturgy of the Eucharist. While the liturgy of the word comprises the readings, homily and general intercessions, the liturgy of the Eucharist is characterised by the presentation of bread and wine, the consecratory thanksgiving and communion. It is now a common phenomenon that during the celebration of this "one single act of worship" (Paul VI. 1963, Sacrosanctum Concilium 56, 1963) visible manifestations of evil spirits can be detected at particular stages.

According to the researchers' findings, particularly in Harare and Mutare Catholic dioceses, irrefutable evidence of spirit possession sometimes occurred during gospel reading. In one of the many deliverance sessions attended by one of the authors, the officiating priest first announced that God's word would minister to the congregation on that particular day. Ironically, as the priest read the gospel passage, spirits began to manifest but he did not immediately attend to them as he continued with the normal Mass procedure. Having gone through several stages, Mass was again interrupted by more or less similar spirit manifestations during consecration time, a stage which for Catholics represents the heart and summit of the Eucharistic celebration. Since such manifestations were not violent and in no way a threat to other congregants, the officiating priest once more ignored the affected persons and continued with the prayer of consecration, reverently calling upon Christ to change the bread and wine into his body and blood. ${ }^{7}$ The officiating priest only came to the rescue of the affected persons just before the reception of Holy Communion, when he lifted the holy bread and commanded the stubborn and adamant spirits to go back to the sender in the name of Jesus. On that day, the exorcist's back-to-sender pronouncements were brief but effective. As a result of his powerful pronouncements, in no time, normalcy returned and the enthusiastic participants received Holy Communion amidst electrifying singing

6 In the Christian religion, particularly among Catholics and Anglicans, Holy Mass or the Eucharist is the main ceremony in which believers eat bread (Body of Christ) and drink wine (Blood of Christ) as a way of remembering Jesus Christ's last meal and supper with his disciples before he died, according to the Bible. In some Christian denominations in Zimbabwe, Africa and the world over, the ceremony is called Communion or Holy Communion concerning the unleavened bread and wine that are used in the ceremony. It is so called and expressed in many other names that evoke fundamental aspects of it.

7 However, it sometimes involved violent dramatic phenomena such as the possessed person shouting in church, falling awkwardly on the floor, violently shaking and beating up people or threatening to knock the officiating priest down; exorcists often took immediate appropriate action and dealt with such stubborn spirits decisively. 
of communion and other praise and worship songs (Charity Chidziva, Interview 12 August 2018).

\section{Deliverance during Benediction or Adoration}

It is also a common practice among the Catholic charismatic renewal demon fighters to conduct their healing sessions during the much revered time for Benediction (Theresa Konza, Interview 15 July 2018). In the liturgy of Holy Communion or Mass, the Roman Catholic Church expresses her faith in the real presence of Christ under the species of bread and wine by, among other ways, genuflecting or bowing deeply as a sign of adoration of the Lord. The Catechism of the Roman Catholic Church (1994) stipulates that the church has always offered and still offers to the sacrament of the Eucharist the cult of Adoration, not only during Mass but also outside of it, reserving the consecrated hosts with the utmost care, exposing them to the solemn veneration of the faithful.

Drawing on the research from the two aforementioned dioceses, the authors observed that the procedure for deliverances during Benediction or Adoration is, however, brief but not so different from the previous two, namely, deliverance within and outside Mass. Deliverance and healing during Benediction often begin with the exposition of the Eucharist, which is procedurally followed by the singing of praise and worship songs. As earlier mentioned, the electrifying environment that is sometimes created by the singing of praise and worship songs often triggers spirit manifestations, with victims inhaling and exhaling sharply. Laying of hands upon the afflicted and the back-to-sender pronouncements often occur simultaneously. In extreme cases like violent attacks that often threaten the life of the victim, sacramentals such as holy water, cross and incense, among many others, would be used. In some cases, the exposed Eucharist used for Benediction can as well be used to expel some cheeky, stubborn and violent evil spirits. It is also a common practice among many Catholic exorcists to start with Benediction and Deliverance, leading them into normal uninterrupted Mass or to begin with the normal Mass procedure, which of necessity would then lead into Benediction and Deliverance respectively.

\section{Deliverance during All-night Prayers}

Healings and exorcisms during All-night Prayers are, perhaps, the most common and popular, drawing thousands of participants from various parishes and dioceses, including priests, brothers, nuns and even some bishops. Participants and enthusiasts have also graced such sessions from other Christian denominations (Theresa Konza, Interview 15 July 2018).

While the procedures for midnight healing sessions often differ from minister to minister, these most fancied and crowd-pooling healing sessions often comprise some spiritual exercises such as spiritual input from a guest or guests, recitation of the rosary, two Masses (opening and closing) and Lectio Divina, among others. These spiritual exercises are often punctuated by some powerful, exhilarating and carefully chosen 
electrifying hymns from all the eight Catholic dioceses in Zimbabwe. Extra-ordinary displays of power by most ministers, public demonstrations of gifts such as prophecy, miracles and speaking in tongues, as well as individual vocal prayers and testimonies by some enthusiastic participants often characterise such "nocturnal" healing sessions. There are also signs of diabolic attacks such as visible supernatural abilities among some victims, bellowing, frenzy or rage, unnatural bodily postures, chaotic scenes like rolling and shouting uncontrollably, among many other outward signs and visible cases of spirit possession (Anonymous, Interview 10 August 2018). It is during such a time of heightened healing expectations that more praise and worship hymns are sung while exorcists would courageously confront the affected, hoping to conquer and send the evil spirits back to haunt their owners. This is followed by even more powerful, electrifying and magnetic pronouncements of the back-to-sender concept that often knock several participants down. Singing continues uninterrupted until normalcy is retained.

With the back-to-sender concept so profoundly illuminating and dominating all healing sessions, it has, however, become more or less fashionable that during most midnight healing sessions, the actual deliverance session, which is the defining moment, begins some time around midnight. The midnight healing session, which in most of its essentials largely resembles Pentecostal healing styles, with some dramatic displays of supernatural abilities and skills by some exorcists, is often followed by a closing Mass around dawn that understandably often leaves congregants physically exhausted but spiritually strengthened and energised (Thomas Chafa, Interview 10 August 2018). Perhaps to analyse and examine this popular healing style, it is essential and academically meritorious to first examine the basis or contexts within which the backto-sender concept and theology possibly emerged. Therefore, to establish this basis, two key sources are critical in this analysis, namely, the African Traditional Religion (ATR) and sacred scripture.

\section{Back-to-sender Concept in African Traditional Religion}

Despite modern education and religions like Christianity and Islam, the belief in vengeance magic is still deeply rooted in African life (Mbiti 1975, 164). The belief in vengeance (kutsiva/mastive) is thus central among the vaShona people of Zimbabwe, just as it is in all African societies. Kutsiva or matsive, the act of taking revenge to harm or injure someone in retaliation for something harmful they would have done against someone, his/her household, animal and fields can be physical or through vengeance magic or wizardry. Among the AmaNdebele people in Zimbabwe, they talk of Ukubuyisela (vengeance) or Ungapindiseli ngemithi (vengeance magic) or go itefeletša (to revenge in retaliation) in Sepedi. The notion of revenge in retaliation is orchestrated by casting a spell called letšwa in Sepedi, hoping to catch anyone responsible for the wrongful acts inflicted upon the victim. The idea is to inflict malicious damage on the perpetrator's body and soul and his or her accomplices. In a broad sense, letšwa is both offensive and counteractive; in a sense providing counteraction, counter aggression, and ushering in restorative justice. Thus, when things go wrong, particularly in a traditional 
African society, especially the vaShona society, people often suspect that someone has used bad magic, sorcery or witchcraft against them, and society always makes frantic efforts to right the wrong to prevent such things from recurring.

There are endless methods of vengeance magic among vaShona people. These can be orchestrated through incantations, words or rituals. It is a common practice within the vaShona society to raise the spirit of the dead person so that it becomes an avenging spirit (Ngozi). Through unlimited powers of African divination, it is also a glaring phenomenon among the Shona people simply to return to sender (kudzosera kwazvabva) any evil magic, sorcery or witchcraft that militates against human progress and wellbeing.

In its classical setting, the back-to-sender concept and methodology at the centre of most contemporary healing practitioners (including Catholic exorcists) is intrinsically linked or resonates well with African traditional healing praxis manifest in the causal explanations, diagnosis and therapy. From an African (Shona) perspective, life is a constant battle and struggle for health, fortunes and prosperity. To a larger extent, coming to grips with the problems of sickness and disease, employing physical and/or spiritual means to cure, heal or protect themselves against enemies of society is, therefore, not an option. As underlined in earlier segments, witchcraft is understood as the epitome and representation of evil, the cause of all misfortune, disease and death. As an enemy of society capable of shutting other people's doors of opportunities, the witch is, therefore, the most hated and feared person in Zimbabwe's multi-ethnic society. For that reason, there was a time when people who practised witchcraft were subjected to severe punishment, torture, and even death in Zimbabwe's chequered history.

Mbiti $(1975,165)$ and Gelfand $(1976,59)$, among many other authors, allude to how enemies of society and other bad people are treated when the two authors separately explore the concept of health and healing within the African context. As underlined by Mbiti, when something goes wrong in the welfare of an African individual or his/her family, be it sickness or affliction, barrenness, death, curses, spells or any misfortune, he/she wonders who has caused it to happen. As earlier underlined, for a genuine African, it is, therefore, not enough to answer how something has gone wrong or diseases are caused. In most cases, as suggested by Mbiti, when confronted by such dicey and difficult situations, a true, undiluted African always suspects that someone has used evil magic, sorcery or witchcraft against them or their household. Such negative plans that militate against other people's breakthroughs are mostly reported among relatives and neighbours (not necessarily strangers), with domestic tensions and jealousies often among the key causes and motives. By blaming someone who perhaps has the knowledge, powers or skills (acquired or inherited) to manipulate, trap and control certain mystical forces in the universe to the detriment and downfall of other people, concerned people are then able to look for a solution which is appropriate and apt. Since the assumption is always that a person, through some evil influence of a 


\section{Mudyiwa, Mokgoatšana}

spiritual nature has caused the misfortune, in most cases, the cure always consists in eliminating the harmful spiritual influence. It consists of confronting and conquering the hated and feared cause. While the cure may sometimes consist in making peace with some angered ancestral spirits or approaching the suspect directly, sometimes it is deemed necessary to repress, conquer and subdue the sheer malice of some hostile evil forces by applying magical means even stronger and more evil; thus possibly triggering off a spiral of reprisals and counter reprisals (ZCBC 1989, 17).

For that reason, in traditional African circles, each community has ways and means of cleansing, curing or counteracting those suspected of disadvantaging others through the use of witchcraft or evil magic; those that possess evil powers that hate to see other people's breakthroughs. Through the use and intervention of medicine men and women, herbalists, diviners, priests/priestesses and many other mediums, Africans try to put right what would have gone wrong in their society. Through them, they try to heal, cure, protect, drive away evil, counteract or neutralise any evil forces targeted at innocent individuals. For Mbiti (1975), men and women with skills and knowledge to combat and counter, confront and conquer such efforts of mystical evil are often referred to as friends of the society. Through their prayers, rituals and sacrifices, friends of society are believed to be the most reliable channels of good health, good fortunes, fertility, peace and welfare.

Thus, from an African perspective, one who gets other people into trouble can always expect some form of revenge (Gelfand 1976, 94). While the offended may not necessarily repay equally the evil done to him or her, it is believed that in some cases, revenge is carried out directly by one's paternal or maternal ancestral spirits through the assistance and direction given by the friends of society. Through their skills, knowledge and ability to tap, use and control the mystical forces and powers in the universe, bad charms, lightning, demons or any other misfortune may be sent back to haunt their owners. For that reason, taking cognisance of the fact that most contemporary exorcists on the African continent and in Zimbabwe, in particular, are African Christians with an African background, the fact that they may at times influence or be influenced by their common African cosmological system of thought may, therefore, not be hotly contested.

\section{Back-to-sender Concept in the Old Testament}

A quick scan through the scriptures reveals that the back-to-sender concept possibly finds its anchorage and pivot on the Old Testament, particularly the ancient and widespread Mosaic Law and the judiciary system of the Israelites. Revenge, retaliation and hatred of one's enemy and/or potential enemy is also explicitly commanded in the Dead Sea Scrolls and the extra-biblical Book of Jubilee (Nolan 1976, 60). As underlined in earlier segments, the back-to-sender concept implies elements of revenge, retaliation, an eye-for-an-eye, and a tooth-for-a-tooth. It implies paying back evil with the same measure, or even more as alluded to in several Old Testament passages. Reading through the books of Exodus and Leviticus, while Moses on the one hand encourages a love of neighbour, on the other hand, he seems to glorify the hurting of enemies and 
outsiders. Thus, he writes: “... You shall give life for life, eye for an eye, tooth for tooth, hand for hand, foot for foot, burn for burn, wound for wound, stroke for stroke" (Ex 21:34).

Even though there may be no explicit indication and verification that the Mosaic principle was followed to the letter as underlined by Crosswalk (2018), it is highly probable that some key Old Testament figures, subsequent patriarchs/matriarchs and prophets were inspired by the same principle. Even though there is no theological consensus that David is the author, in his many passionate prayers in the Psalms, King David is one of those who made several critical pronouncements against his enemies and potential enemies, dead or alive. The following verses testify to this claim and observation. "Let destruction come upon them unawares and let their nests that they have hidden catch themselves, into that destruction, let them fall" (Psalm 35:8). "They will fall into the pit they have made for me. Their mischief shall return upon their heads; their brutality falls back on their skull" (Psalm 7:15-16). "O Lord, according to your word, let evil slay the wicked and make those that hate me desolate" (Psalm 34:21). As if to concur with Moses and the Psalmist, the prophet Jeremiah also had some bitter wishes against his enemies. He underlined: "Let my persecutors be confounded, not I, let them, not me, be terrified. On them bring the day of the disaster, destroy them twice over" (Jer 17:18). Earlier in the book of Genesis, Yahweh Himself is also pictured to have declared thus: "If anyone kills Cain, sevenfold vengeance shall be taken for him" (Gen 4:15).

While the list of verses that seem to justify revenge and the back-to-sender concept are endless, it is with little doubt that this ancient Mosaic principle, worth appreciating and understanding in its historical and classical setting, has since shifted significantly. Moving out and further away from its classical civil context, the principle, which is believed to have originated from the code of Hammurabi (Crosswalk 2018), has found its way into contemporary religious settings whereby the practice of punishing the guilty, those who get others into all forms of trouble whether on the physical or spiritual realms, recognised or potential enemies, is now prevalent among Christians of diverse beliefs and practices, including African Christians. Equipped and loaded with scriptural texts that seem to justify their most fancied healing methodology, frontline Catholic charismatic exorcists have all the reasons to glorify, venerate and magnify the back-tosender concept. However, even though there is also little doubt that the Old Testament is largely taken as one of the deposits and reference points for the back-to-sender concept by most contemporary healing practitioners, the seemingly biblically based principle was categorically challenged and condemned by Christ in the New Testament.

\section{Back-to-sender in the New Testament and Beyond}

Following a seemingly logical and clarion call for the promotion and amplification of revenge and vengeance in some sections of the Old Testament, the New Testament on the contrary seems to have raised the moral and ethical standards of interpersonal relationships by challenging the back-to-sender practice unconditionally and 
unquestionably. Even though some Jewish sects such as the Pharisees and scribes (particularly during the time of Jesus) visibly applied this law of revenge literally in their relationships, the New Testament has its distinctive character largely modelled on the primacy of love, non-violence and non-retaliation. Hence, during the time of Jesus, upon whom the meaning and message of non-retaliation find its pivot and leverage, nothing could be more radical and revolutionary than contradicting or condemning the widespread ancient minimum standard Mosaic principle (Nolan 1976).

It is an apparent fact that the principle of "eye-for-eye" and "tooth-for-tooth" vendettas and blood still existed during the time of Jesus. However, announcing the advent of the New Commandment and dispensation that was not in any way meant to nullify the old Mosaic Law, in unequivocal terms, the New Testament condemns any form of revenge or retaliation and insists on leaving any form of revenge or judgement for God (Rom 12:19). Perhaps one of the most direct and clear passages that condemn violence and oppose the principle of personal retaliation is Jesus' Sermon on the Mount. In his famous teaching during the Sermon on the Mount, Jesus emphasised the significance and value of unconditional love ${ }^{8}$ as he articulated the New Commandment that was perhaps meant to pervade all spheres of human relationships for all generations. Referring to the ancient Mosaic principle, he underlined:

You have learnt how it was said, an eye-for-an-eye and a tooth-for-a-tooth. But I say this to you: offer the wicked man no resistance. On the contrary, if anyone hits you on the right cheek, offer him the other as well. ... You have learnt how it was said: "You must love your neighbour and hate your enemy." But I say this to you: love your enemies and pray for those who persecute you ... (Mt 5:38-45)

While enemies may take different forms, shapes and sizes, in contemporary social settings they may also include those who use witchcraft or magic against others; those who manipulate forces of nature to cause harm or injure the innocent, or those who mysteriously shut doors of opportunities for others. Therefore, for Christians, the implication would mean that even if a person has been wronged, insulted or bewitched, one is not obliged to avenge the injury in any way. Besides, assuming that one has discovered through other overt or covert means the person or people who have killed or are planning to kill their family through magic or witchcraft, as finite and sinful beings, the New Testament discourages all followers of Christ from taking matters into their own hands. Instead, just as ATR sometimes teaches that revenge is carried out by ancestral spirits (Gelfand 1976, 95), the New Testament encourages the offended to rather allow God to bring wrath and vengeance Himself, for He categorically made it known that "vengeance is mine" (Rom 12:19). For that reason, since two wrongs do not

8 There is, however, one difficulty with Jesus' interpretation of neighbour and/or enemy. He confined his activities to Israel and instructed his disciples to do the same (Mat 10:5-6). The Gospel of Matthew also reports that he hesitated to help the Canaanite woman (Mat 15:24), underlying that it was not proper to take children's food and throw it to the dogs (Mat 14:26, Mk 7:27). However, having made these remarks, eventually, Jesus helped the woman just as he did the Roman Centurion (Lk 7:3-5). 


\section{Mudyiwa, Mokgoatšana}

make a right, no Christian or exorcist may declare a solemn utterance or offensive word or statement directed or intended to invoke supernatural powers to inflict harm or punishment on someone, whether the utterance is spoken in anger or ecstasy.

A handful of other verses throughout the entire New Testament also condemns any form of revenge and/or retaliation, physical or spiritual. In his instructions that guide interpersonal relationships, Peter advised Christians never to pay back one wrong with another, or an angry word with another. Instead, he encouraged them to pay back any wrongdoing with a blessing (1 Peter 3:9). Earlier in Chapter Two, Peter had also hinted that Jesus, who happens to be the model par excellence for all Christians, was insulted but did not retaliate with insults (1 Peter 2:23). Similarly, Paul also tipped the Romans, "Do all you can to live at peace with everyone. Never try to get revenge; leave that, my friends, to God's anger (Rom 12:19). Bless those who persecute you; never curse them, but bless them" (Rom 12:14). "Never repay evil with evil but let everyone see that you are interested only in the highest ideals" (Rom 12:18). A lot more texts testify to this non-violence and non-retaliation principle throughout the entire New Testament.

Perhaps as an extension element of his main mission and the gospel of non-retaliation, during his time on earth, Jesus also performed countless exorcisms using various healing methods (Nolan 1976, 30-31). The most common method that he used was the laying on of hands, along with speaking the Word as with the cure of Peter's mother-in-law (Mat 8:14). Sometimes, as with the daughter of the Canaanite woman, the exorcism took place from a distance (Mat 15:22). Jesus drove a legion of evil spirits out of a demoniac living in a cemetery and made them enter a herd of swine (Lk 8:26-39). As with the man born blind, Jesus used both physical contact and other means such as the use of clay made from spittle. The use of spittle was a popular remedy of blindness during that time (John 9:6). He could also use the faith of the receiver, as with the case of the Centurion's servant (Mat 8:5); by the faith of another as in the case of the cure of the paralytic (Mat 9:2-7); or by prayer as in Mark 9:29.

As the premier exorcist of all time, before he ended his earthly mission, Jesus commissioned and empowered his apostles and future disciples to cast out demons in his name (Mat 10:1). Apparently, throughout their ministry as well, in a more or less similar fashion, his disciples furthered their Master's healing ministry and techniques. The ability to cast out evil spirits that were bestowed on them was, therefore, a sign of true discipleship among members of his inner circle. The same power was also promised to those who believe in him (Mk 16:17). In the Gospel of John, Jesus made a clarion call that whoever believed in him would perform the works that he performed, or even greater (John 14:12). To both disciples and believers, conspicuous victory and success were thus promised. For that reason, the apostles continued the work of healing and deliverance (Acts 3:7). The New Bible Dictionary (1996) confirms that healing and exorcism were not just common in the apostolic era but became an important part of the tradition of the early Christian church. The same legacy continued in the early church and beyond, save for some disturbances during the period of the enlightenment 
(Brockman and Pescantini 1991). However, the period of the late Middle-Ages witnessed a revival of the ministry of healing, but the practice took yet another decline in the 20th century.

While the Roman Catholic Church has always maintained a traditional but cautious position regarding exorcism, over the centuries she has produced countless professional exorcists who claimed to have the power and ability to cast out evil spirits; and apparently, they sometimes succeeded in doing so. In most cases, the professional exorcists attributed their success to the precise observance of some ancient formula or method like praying the Rosary, the use of incense, crucifix, holy water or Holy Communion. In other cases, the ritual would include incantations and many other dramatic symbolic actions, but the methodology had not yet adopted the back-to-sender concept.

The back-to-sender pronouncements seem devoid of New Testament support since nowhere in the Bible did Jesus or his disciples apply this most fancied principle. As underlined in earlier segments, Jesus never made use of any kind of ritual formulae, incantations or invocations of names during his time on earth. Thus, it is very likely that he was accused of exorcising in the name of Beelzebul or Satan (Mat 12:22-32) precisely because he had not invoked any other authority nor used any traditional ritual, much to the surprise of his ear and eyewitnesses (Nolan 1976, 30). When he (Jesus) drove a whole legion of evil spirits, 2000 in number, he made the evil spirits enter a herd of swine upon their request (Lk 8:26-39). He did not perform any witch-hunting exercise to identify the owners (if any), wish them dead or suffer the same fate. Neither was the eradication of poverty and suffering, which is topical to date among preachers of prosperity, an integral element of his mission. The same applies to all his healing miracles. In as much as he underlined that he was sent to bring the good news to the poor, to proclaim liberty to captives and the blind new sight, to "set the downtrodden free and to proclaim the Lord's year of favour" (Lk 4:18), he also categorically stated that "you have the poor with you always" (Mat 26:12). With this statement, Jesus perhaps implied that no subsequent professional healer or exorcist would do away with poverty, sickness and suffering as suggested by some self-styled healers on the Zimbabwe Christian landscape. Key drivers of the back-to-sender concept have so far implied that they have the knowledge, power and ability to scatter into desolation, and back to their owners, every power that makes people suffer affliction, sickness or even poverty. For this and many other reasons, the ZCCR has, understandably, been met with mixed feelings on the Zimbabwe Christian landscape.

\section{Impact and Implications}

Ever since the revival of the seemingly slumbering and sluggish Catholic charismatic renewal and the introduction of healing and deliverance services as an "alternative therapy" by some Catholic exorcists, the new trajectory has had a double-folded impact on the Zimbabwe Catholic Church. While on the one hand the new development and dispensation in the Roman Catholic Church were viewed as complementing and 


\section{Mudyiwa, Mokgoatšana}

possibly completing the already existing Catholic health delivery system and traditional Sacrament of the Anointing of the sick, on the other hand, the calling back to life of the seemingly dormant CCM was seen as a dilution of pristine Catholic practice (Midzi T., Interview 15 August 2018).

As earlier underlined, on the African continent, statistics have always indicated that the ministry of healing and deliverance has been on the ascendency every day among independent churches, Pentecostals and some charismatic healing communities. Prophets from African Independent movements, for example, are constantly in the news, alongside advertising their healing competence on various signposts in urban areas (Gundani 2001, 136). The same healing services have also been repeatedly and consistently used as a recruitment technique among such healing movements. Consequently, as a result of such rapid growth and influence, several Catholics either converted to the seemingly fashionable charismatic healing communities or sneaked out of their traditional church in times of serious illnesses to look for healing from quarters not in league with their Mother Church. Apparently, this had created an unchallenged culture of double-dealing and double-faced Christians within the one, holy Catholic and Apostolic family for decades. Perhaps in a bid to bridge the gap and address such an anomaly, key drivers of the ZCCR stepped in to provide the needful, thereby making the Zimbabwe Catholic Church more alert and attentive to the signs of the times (Stella Gomba, Interview 10 August 2018). Additionally, not only was the Catholic charismatic renewal commended for breaking with the past by introducing the much-awaited "alternative therapy" in the Zimbabwe Catholic Church, the coming on board of Catholic lay ministers to complement and possibly complete the work of the priests was also viewed as a welcome development.

However, despite the many advantages brought about by the CCM, the same movement has also had a fair share of criticism from several Catholic quarters in Zimbabwe. Of all the criticisms levelled against the Catholic charismatic exorcists, perhaps the most pronounced is centred on the borrowed back-to-sender concept which has been viewed as having a more Pentecostal dimension that is not compatible with Catholic practice and theology. Thus, apart from the seemingly controversial back-to-sender methodology that is foreign to Catholic praxis and contradictory to a Christology of non-violence, since charismatic exorcists incorporate elements of both Catholic and charismatic practices, the Catholic charismatic renewal activities have also been accused of distracting Catholics from authentic teachings and traditions, particularly by making the worship more akin to Pentecostalism. In other quarters, ironically, charismatic services have been said to have helped in increasing the number of Catholics converting to Pentecostal and evangelical denominations. The desire to get charismatic and Pentecostal-like services on a much more regular basis was cited as a pull factor, thereby suggesting that some regard charismatic renewal services as catholicon or panacea for all their problems. For that reason, practices such as deliverance, healing and exorcism have been accused of drawing Christian attention away from the Holy 
Mass and communion with Christ, who is the abridgement and summation of the Christian faith (Catechism of the Roman Catholic Church 1994, 336).

More still, in direct violation of Jesus' instruction that "You received without charge, give without charge" (Mat 10:8), some Catholic exorcists have also been accused and criticised for asking their clients to pay some token of appreciation or strategically organising their deliverance sessions in places and parishes where they know they would get bigger collections. The same point was also underlined by Chitando et al. (2013, 9) in the book, Prophets, Profits and the Bible. In this Festschrift, some contributors have explored the complexities that characterise and continue to characterise prophets and prophecy in Zimbabwe. A handful of contributors have labelled them "gospel-preneurs" who are always after money. "What is true of Pentecostal prophets may also be applied to a new brand of profit-loving Catholic 'prophets." Following the same logic, instead of deliverance sessions functioning as platforms for "giving freely what exorcists received freely" some healing conferences have been accused of having an underlying agenda of making a few professional exorcists richer through the so-called "love offering." Thus, ironically, this doublefolded impact of the Catholic charismatic renewal has created some visible cracks and a "cold war" within the Catholic family itself, particularly between liberals who seem to be in the majority and conservatives who are in the minority. And understandably so, in contrast to the hostile reactions of some Catholic lay conservatives who are anticharismatic operations, a few Bishops in Zimbabwe have thus maintained a cautious and disengaged approach to the ZCCR.

Upon discovering that the back-to-sender concept contradicted and was not compatible with Jesus' key teachings on love and forgiveness and was not immune to criticism, by the time this research was conducted, efforts were being made by the Zimbabwe Catholic community to try and give back-to-sender pronouncements a new look and theological orientation. From the evidence gathered through interviews, instead of directing all evil forces, powers and principalities of darkness back to haunt their owners, Catholic exorcists were being tipped to direct them to the foot of the Cross (Anonymous, Interview 12 August 2018). The Catechism of the Roman Catholic Church (1994) underlines that for Christians, Jesus' redemptive act was realised and completed on the cross. Thus, the cross is a symbol of victory, redemption and salvation. It contains all the redeeming benefits of Jesus' passion and death. It is, therefore, through Jesus that Christians direct their needs and prayers. They believe that Jesus can intercede for them and save those who pray to God through him. While many Catholic exorcists have accepted the new method of directing evil forces to Christ the Victor, some Catholic quarters, however, still maintain that the back-to-sender methodology can still be used depending on the situation exorcists find themselves in. Thus, even though the ZCCR itself lacks theological evidence either to approve or condemn it categorically, the fact that the debate on healing methodology still rages on is itself reflective of the fact that the ZCCR is a movement of unforeseen and unpredicted impact on the Zimbabwe Catholic landscape. 


\section{Conclusion}

This article has explored the phenomenon of faith healing and exorcism in the ZCCR. The article has established that while healing in the ZCCR as manifest in the causal explanation, diagnosis and methodology, though based on sacred scripture and the unequivocal mandate and command by Jesus to heal and cast out evil spirits in his name, the popular concept of back-to-sender appears controversial, contradictory to and incompatible with Jesus' principle of non-violence, non-retaliation and turning of the other cheek (Matthew 5:38-48). Since the back-to-sender concept implies an "eye-foran-eye" and a "tooth-for-a-tooth" no priest exorcist or Christian may, therefore, as ambassadors of love, forgiveness and non-retaliation, be justified to declare a solemn pronouncement that is directed at injuring or killing another person created in the image of God (Gen 1:26). Thus, despite the positive impact that the borrowed back-to-sender concept has so far enjoyed on the Zimbabwe Christian (particularly Catholic) landscape, the new healing technique is likely to have some long-range disastrous consequences if ecclesiastical authorities continue to employ a wait-and-see policy without regulating the operations of the ZCCR.

\section{Selected Interviews}

Anonymous Priest, Interview on the impact of the Zimbabwe Catholic Charismatic Renewal, 20 November 2020.

Anonymous, Interview on the impact of the Zimbabwe Catholic Charismatic Renewal, 20 September 2018.

Anonymous, Interview on the impact of the Zimbabwe Catholic Charismatic Renewal, 10 August 2018.

Anonymous, Interview on the impact of the Zimbabwe Catholic Charismatic Renewal, 12 August 2018.

Anonymous, Interview on the impact of the Zimbabwe Catholic Charismatic Renewal, 15 August 2018.

Chafa, T. Interview on the impact of the Zimbabwe Catholic Charismatic Renewal, 10 August 2018.

Chidziva, C. Interview on the impact of the Zimbabwe Catholic Charismatic Renewal, 12 August 2018.

Chiraza, P. Interview on the impact of the Zimbabwe Catholic Charismatic Renewal, 20 August 2020.

Gomba, C. Interview on the impact of the Zimbabwe Catholic Charismatic Renewal, 10 August 2018. 
Gomba, S. Interview on the impact of the Zimbabwe Catholic Charismatic Renewal, 10 August 2018.

Konza, T. Interview on the impact of the Zimbabwe Catholic Charismatic Renewal, 15 July 2018.

Midzi, T. Interview on the impact of the Zimbabwe Catholic Charismatic Renewal, 15 August 2018 .

\section{References}

Adarkwa, K. 2015. "The Role of Music in Worship.” Accessed November 28, 2020. Modernghana.com/news/631897/the-role-of-music-in-worship.

Asante, M. K. 1998. The Afrocentric Idea. Philadelphia: Temple University Press.

Brockman, N., and U. Pescantini. 1991. A History of the Catholic Church. Nairobi: St Paul Publications.

Burke, D. 2012. "Lectio Divina: A Guide: What it Is and how it Helps Prayer Life." Accessed November 28, 2020. spiritualdirection.com/2012/04/21/what-is-lectio-divina-and-will-ithelp-my-prayer-life-a-guide-to-lectio-divina.

Chitando, E. et al. (Eds). 2013. Prophets, Profits and the Bible: Festschrift for Aynos Masotcha Moyo. Bamberg: University of Bamberg Press.

Chitando, E. et al. 2014. Multiplying in the Spirit: African Initiated Churches in Zimbabwe. Bamberg: University of Bamberg Press.

Chitando, E., and J. Tarusarira. 2017. "The Deployment of a 'Sacred Song in Violence in Zimbabwe: The Case of the Song 'Zimbabwe Ndeye Ropa Ramadzibaba' (Zimbabwe was/is born of the Blood of the Fathers/Ancestors) in Zimbabwean Politics." Journal for the Study of Religion 30 (1): 5-25. https://doi.org/10.17159/2413-3027/2017/v30n1a1.

Ciciliot, V. 2019. "The Origins of the Catholic Charismatic Renewal in the United States in Indiana and Michigan and the Reactions of the Ecclesiastical Authorities." Studies in World Christianity 25 (3): 250-273. https://doi.org/10.3366/swc.2019.0267.

Crosswalk, D. 2018. “An Eye-for-an-Eye: Biblical Meaning and Significance.” Accessed August 10, 2020. https://www.gotquestions.org/eye-for-an-eye-html.

Daneel, I. 1987. Quest for Belonging. Gweru: Mambo Press.

Discipleship Ministries. 2007. "Importance of Music in Worship.” Accessed November 28, 2020. umcdiscipleship.org/resources/importance-of-music-in-worship. 


\section{Mudyiwa, Mokgoatšana}

Finnegan, R. 2012. “Oral Literature in Africa.” World Oral Literature Series, Vol. 2. Cambridge: Open Book Publishers. http://www.openbookpublishers.com. https://doi.org/10.11647/OBP.0025.

Gelfand, M. 1976. The Genuine Shona. Gweru: Mambo Press.

Grele, R. J. 2007. "Reflections on the Practice of Oral History: Retrieving what we can from an Earlier Critique." Suomen Anthroplogi: Journal of the Finnish Anthropological Society 34 (4): 11-23.

Gundani, P. H. 2001. "Church, Media and Healing: A Case Study from Zimbabwe." Word and World 21 (2): 135-143.

Junod, H. A. 1913. The Life of a South African Tribe, Vol 2. Neuchatel: Imprimerie Attinger Freres.

Karenga, M. 2014. "Kawaida, Cultual Nationalism and Struggle: Setting the Revolutionary Record Straight.” Journal of Pan-African Studies no. 7 (1): 1-6.

Lagerwerf, L. 1987. Witchcraft, Sorcery and Spirit Possession. Gweru: Mambo Press.

Leonhardt, D. J. 2009. “Praying with Scripture.” Accessed November 28, 2020. ignatianspirituality.com/ignatian-prayer/the-what-how-why-of-prayer/praying-withscripture.

Manneh E. 2020. “Lectio Divina: A Beginner's Guide.” Accessed November 28, 2020. Bustedhalo.Com/Ministry-Resources/Lectio-Divina-Beginners'-Guide.

Matambo, K. 2015. "Charismatic Renewal is all about True Conversion. ZCCR @ 50.” Accessed August 10, 2018. www.jesuitszimbabwe.co.zw/index/php/contact/770charismatic-renewal-is-all-about-conversion.

Matsikidze, K. P. 2015. "Catholic Charismatic Renewal: A Panacea for Catholics who want to be Pentecostals?" Accessed September 20, 2020. www.jesuitszimbabwe.co.zw/index/php/2015-01-05-16-44-03/Mukai-Vukani.

Mbiti, J. S. 1975. Introduction to African Religion. London: Heinemann.

Mudyiwa M. 2016. “An Investigation into the Impact of Supa Roma’s Healing Ministry on the Roman Catholic Church in Zimbabwe: A Case Study of Gweru and Masvingo Catholic Dioceses.” Unpublished MPhil thesis, Harare: University of Zimbabwe.

Myers J. (s.a). “Is Sheep Stealing Okay?” Accessed November 27, 2020. redeeminggod.com.

Mokgoatšana, S. 2020a. "Controversial Contradictions in Testimonies about Manche Masemola: The Challenge of Variability in Oral History." Studia Historiae Ecclesiasticae 46 (1): 1-21. https://doi.org/10.25159/2412-4265/7467. 


\section{Mudyiwa, Mokgoatšana}

Mokgoatšana, S. 2020b. "The Monstrous and the Grotesque: (De)Scribing and Unmasking Eschatology in Sepedi folktales." Theologia Viatorum 44 (1).

https://doi.org/10.4102/tv.v44i1.72 .

Nolan, A. 1976. Jesus before Christianity: The Gospel of Liberation. London: Longman and Todd.

Paul VI. 1963. Sacrosanctum Concilium: The Constitution on the Divine Liturgy.

Shoko, T. 2006. "Super Roma: Towards a New Theology of Healing in the Roman Catholic Church in Zimbabwe." Swedish Missiological Themes 94 (3): 349-370.

Sibanda, C. 1999. "An inquiry into the Ministry of Fr Augustine Urayai.” Unpublished BA Honours Dissertation. Harare: University of Zimbabwe.

The Catechism of the Roman Catholic Church. 1994. Nairobi: Pauline Publishers.

The Jerusalem Bible. 1966. London: Darton, Longman and Todd.

The New Bible Dictionary, 3rd edition. 1996. Leicester: Intervarsity Press.

Zimbabwe Catholic Bishops Conference (ZCBC). 1989. "Healing and Salvation in the Church, Pastoral Letters," Volume 2.

Zvarevashe, I. M. 2005. Authentic Inculturation and Reconciliation: A Catholic Perspective. Lusaka: Mission Press. 